POLIGRAFÍAS. REVISTA DE TEORÍA LITERARIA Y LITERATURA COMPARADA. NÚMERO 1. NUEVA ÉPOCA.

() UNAM TODOS LOS DERECHOS RESERVADOS

https://doi.org/10.22201/ffyl.poligrafiasnuevaepoca.2011.1.1652

\title{
Flaying the Image: \\ the body of the anatomical theatre in purview of Walter Benjamin's work on allegory and the baroque
}

\author{
YAOCÍ PARDO-DOMÍNGUEZ \\ University of Western Ontario
}

...the image is a fragment, a rune.

Walter Benjamin

The Baroque coincides with the development of a new art, a technique that learned how to read the confessions of the body, one that knew with precision how to bring the body out of its deadly silence and make it confess. This was not the tribunal of the Inquisition; this was the Anatomy theatre whose imprint bore the character of the scalpel. By laying out the canvas of the corpse, the amphitheatres showed a figure appearing upon the very same folds under which it disappeared. In the anatomy lesson, the act of reading coincided with an act of writing: the knife wrote as it read. The anatomist conceived a carte blanche, a blank map whose contours were traced on the selfsame edges of the parchment. For the first time-it seemed - the portent of veils gave straight answers. The magistri vulnerum - the masters of wounds-sought to undo the body in order to gaze at the nakedness of Eden; their most prized text being the silence written on Adam's coat of skin. Such was the dream of the anatomist: to hold the image of man in one piece. Piece by piece.

Of Albrecht Dürer's Melencolia, Benjamin observes “The Renaissance explores the universe; the Baroque explores libraries [...] The 'Book of nature' and the 'Book of times' are objects of baroque meditation" (1977: 140). In this sense, the year 1543 was a true annus mirabilis, one of crucial consequence in the understanding of the baroque scene. There appeared Copernicus' De revolutionibus orbium, Leonard Fuch's second edition of the botanical catalogue De historia stirpium and Vesalius' De fabrica corporis humani. Copernicus had displaced the centre from the earth to the sun; Vesalius brought the centre down to earth. Fuch had collected a multiplicity of flowers, fruits, plants and seeds and attempted a catalogue of their appearances 


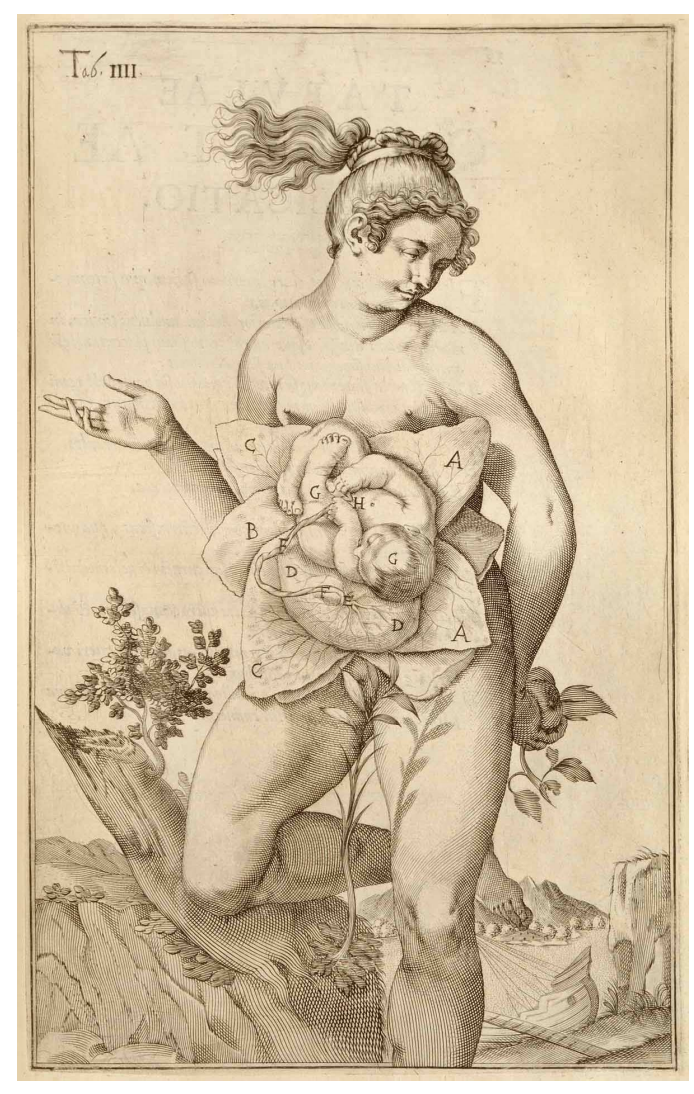

FIG. 1: De formatofoetu...

Frankfurt, 1631.Copperplate engraving.National Library of Medicine.

Giulio Casserio(ca. 1552-1616)[anatomist]

OdoardoFialetti[artist]

In Adriaan van Spiegel(1578-1625)

The plates for Casserio'stheatrumanatomicum were printed after his death in works attributed to him and his pupil Adriaan van Spiegel. Here, a pregnant woman is dissected so that the flaps resemble petals of a flower, with the baby at the center. and medicinal virtues; Vesalius made the body bloom in the most varied ways on the dissecting table. [Figure 1]

Vesalius' revolution consisted of elucidating the authority of the body vis-à-vis the written text; and to that purpose he had to had to redress it. Vesalius designed a new kind of anatomy book, a corpus where pictures figured prominently and the text was indexed to the tissue of an image. The anatomical plates included in De fabrica had all been drawn during actual dissections. Their purpose was to act as universals.

Until then, the errors found in the Galenic postulates had been attributed to something other than the Galenic method. When the anatomist faced an incongruence, the corpse had to be wrong, Galen, never. To this respect, Jacobus Sylvius, a contemporary of Vesalius, even speculated on the possibility of human involution. It was not really because Galen had only dissected and vivisected pigs, dogs and monkeys-even an elephant-that his

texts seemed incongruent with human anatomy, it was because ever since the great fall, the body had progressively degenerated, and the new generations were not what they used to be. Adam and the race of the giants-argued Sylvius - had been the true men. Galen had only been a spokesman of how perfect the body of the creation had once been, and that ought to be the image of man preserved - the image in the likeness of God.

Discussions such as the latter were just a sign of how anatomy until then had been primarily conceived of as an imperfect reference to ancient knowledge. Discerning disease from perfection within the body had been not a matter of corroborating empirically but of identifying 
and naming the structures below the surface according to the scholastic text. Anatomy and medicine had been confined to a paradigm that was entirely mediated by hefty volumes of ancient tissue. Endless disputes arose over the names of diseases, structures and organs when comparing the findings of the modern amphitheatres to the postulates of the Articella-the textbook of medieval medicine-or Galen's De Usu Partum-On the use of the parts. Finding the right name was of utter importance because the genealogy of the body was understood as a philological reconstruction. ${ }^{1}$ Adam had named "every beast of the field and every fowl of the earth", he had found a name for "Eve" and, in legend, had even given both God and himself a name. ${ }^{2}$ He was the name-giver; and as such, his word mattered. Like a subtle knife, his tongue had cut through the fabric of the world; even his body could not be understood but as the result of one cut: a deontological act of suppression had brought about two and then the world was fruitful and multiplied. The endeavour undertaken by philology had been to seam back the ripped cloth to its original state in order to understand the greater scheme, the loss of Babel. The word was the law, if it was the right word. But an irresponsible multiplication of the names, who knew what could bring about? Cuts here and there that would shred to pieces the precious shroud of the corpus of knowledge. The multiplication of names among the erudite, meant Babel, worlds upon worlds precariously built that would eventually crumble to nothing. Vernacula were of too recent an origin to convey what would best approach the language of Adam; the corpse had to be observed preferably within the margins of a dead language.

Consequently, the use of the image in anatomical practice became highly debatable. For people like Sylvius, the problem that images posited was that, in time, they would prove theoretically obsolete because they were recording a transient instant; images were deemed to be the museum of distorted essences generated by the imperfection of time. The image-as it

\footnotetext{
1 "In some sense the vernaculars were not proper languages, and a new disease like the French Disease could not be handled by the apparatus of medicine until its proper, ancient, name had been discovered: its vernacular name was merely accidental. When Latin humanists grumbled about being isolated in a sea of rusticity and barbarity, they meant the tide of technical Latin of the schools. When Hellenists grumbled in the same way, they meant simply Latin. Their own language, Greek, was after all older and more pristine than Latin" (French, 1999: 144).

2 "According to a traditional account, God, desirous of establishing closer relations with man, asked Adam to name Him (a request man could neither evade nor decline), Adam, quoting Scripture, complied: 'It is fitting for Thee to be called Adonai since Thou art Lord of all Thy creatures, for it is written $<<$ That is my name, $>>$ which means, that is the name by which Adam called me."' And further: "It is befitting that I be called Adam because I come from the earth, adamah" (Jacobs, 1958: 25-26).
} 
was argued-misguided the practitioner; it merely led him to misread the knowledge that had been zealously preserved over the centuries by the scholastic text. If there were to be any images done at all, the images should try to approximate the eternal, the universal, and not be the product of a contingent particular: from particulars one could not infer universals; any/body could in no way represent the body of mankind. The image of temporality posited the problem of robbing the fallen creature even from the trace of its godly nature.

Images were not only deceiving but the embodiment of obsolescence. Already the advent of the Reform had questioned their use (and this, not considering that the world of Islam had since its beginnings professed a mistrust of images-also shared, though for different historical reasons, by Byzantine Orthodoxy - much before this crisis in the Catholic faith). The pre-reformed Church had until then used the image as a vehicle of divine ineffability; the devout medieval mind understood contemplation as an image-the suffering body of Christ. The image had been hypostasised by faith. By denying the doctrine of Transubstantiation, Protestantism impinged on the very nature of signification. It broke apart the relation between signifier and signified - the Host and the Divine. "Images of the sacred suffering body were doubly suspect for being at once visual and corporeal" (Owens, 1994: 9). The image was forsaken by its transcendent substance and subsumed in the materiality of its historicity. For Benjamin this would become "the heart of the allegorical way of seeing, of the baroque, secular explanation of history as the Passion of the world [...] the greater the significance, the greater the subjection to death, because death digs most deeply the jagged line of demarcation between physical nature and significance" (1977: 166).

Even beyond Adanic genealogies, pictures were at odds with classification, for if pictures ever came to represent the all too mutable appearances of things, far too many of them would be necessary: infinity was heresy. ${ }^{3}$ Furthermore, the artist could always import a subjective element in order to approximate his appreciation of the object to a specific idea. To the empirical mind, it was important to represent the multiplicity of nature, but if possible, to avoid it seem like a chaotic display of difference, anomaly and failure-a cabinet of wonders.

\footnotetext{
${ }^{3}$ Linnaeus, the cataloguing mind of the XVIII century, would much later reprise the debate of this very same question for the very same reasons.
} 
The miscarriages of nature were ludi naturae, games, plays, with which natural forces amused themselves; but it would be of dire consequence if even the thought of a God deceiving the senses entered the mind. The catalogues of botany, zoology, the treatises on anatomy needed a cataloguing machinery, a language that made them sustain their endeavours from the fallen nature of things, a means to defeat the guilt-laden randomness of the collector's dice. The more ambitious, however, a project progressively became, the more the catalogues dissolved into mere subjective collections in their frustrated attempts at producing a system that could organize and comprise the information. After all, what prevailed not only after the catalogue but before the catalogue was the collection.

The uncertainty created among difference, anomaly and normalcy immediately called for a need to broaden the field of experience. The objects needed to be touched, seen, savoured: its extravagant materiality was proof of their existence, as only miracles and revelation shunned doubt on the profane world of profusion. The notions of the universal were to be derived from exhaustive subjectivity. Not knowing what things should look like made it hard to tell what they did look like, precisely because representation seemed to inevitably step in with a should which was, rather, apodictic. This produced an increasing awareness that the language of representation imposed the limits of human cognitive perception. The image went beyond the realm of names and plunged into the unbound space of judgement. And judgementdiscernment-had gained for mankind the loss of paradise. ${ }^{4}$

The brush, the ink, the charcoal out/lined categories - created the outlaw figure. Texture was the text of the sensuous. Like the open canvas rendered by the scalpel, the silhouette was included in the figure by means of its own exclusion. The image of the body was ex-sacrated: placed outside the cut. The outline, the contour, the trace approached its subject but never managed to grasp it: it retained the tempting thrust of an invisible presence, a visible

\footnotetext{
4 “The serpent's promise to the first men was to make them 'knowing both good and evil'. But it is said of God after the creation: 'And God saw everything that he had made, and behold it was very good'. Knowledge of evil therefore has no objet. There is no evil in the world. It arises in man himself, with the desire for knowledge, or rather for judgment. Knowledge of good, as knowledge, is secondary. It ensues from practice. Knowledge of evil-as knowledge this is primary. It ensues from contemplation. Knowledge of good and evil is, then, the opposite of factual knowledge. Related as it is to the depths of the subjective, it is basically only knowledge of evil. It is 'nonsense' [...] This knowledge, the triumph of subjectivity and the onset of an arbitrary rule over things, is the origin of all allegorical contemplation" (Benjamin, 1977: 233).
} 
evanescence. The image shared the paradox of being like something that it was not-it was especially not what it looked like.

The terrain of the illustration became an unbound space for analogy. The worlds that, until then, had remained invisible became possible through quotation. Quotation was the fragment that linked the unseen and the unseemly to a history of vision. It was the bridge amidst the dissimilar, "fragments of thought," as Benjamin calls them, that were "all the greater the less direct their relationship to the underlying idea" (1977: 29). By gazing at the ancient hydras and gorgons, the naturalist shed light on the newly discovered species; the physiologist, on the appendix of ulcers. A new type of emblem, materially stripped from the aura of its encrypted meaning, came to represent the insignificant variation of nature, the isolated phenomenon that lacked a sign: it was the result of the endeavour to make time matter.

The new objects were subsumed to the old forms of representation. And in that process they truly became anomalous; they became monstrous at their attempt of monstration. A new fruit resembled a tumour, eczema a lichen, the womb of a pregnant bird a dehiscent liver. Imagery was merged with the imaginary. The scientific illustration grew out of the waters of allegory: the more things were observed, the harder it became to discern them. "It was not their sheer exceptionality that made the monstrous and anomalous what they were, it was the fact that they always retained at least a minimal relation to that from which they diverged" (Freedberg, 2002: 354). The new treatises acquired the dimensions of the Book, the immanence of an entire cosmogony. The Book of Genesis traced its steps back to the genesis of the book. ${ }^{5}$

Categories meant distinctions that all of a sudden seemed to be reduced to nothing because of the sheer incapacity to arrest the wonder. The wonderful was distinct and unclassifiable; it proliferated, each object becoming a species of its own. But the category killed the wonder; it forced the word-order of the knife. The collection, on the other hand, the gobetween the catalogue and the wonder, marked out the limits of human understanding and

\footnotetext{
5 "It will be unmistakably apparent, especially to anyone who is familiar with allegorical textual exegesis, that all of the things which are used to signify derive, from the very fact of their pointing to something else, a power which makes them appear no longer commensurable with profane things, which raises them onto a higher plane, and which can, indeed, sanctify them [...] Allegory is both convention and expression; and both are inherently contradictory [...] just as baroque teaching conceives of history as created events, allegory in particular, although a convention like every kind of writing, is regarded as created, like holy scripture [...] expression of convention" (Benjamin, 1977: 175).
} 
experience. The exceptional was brought together by an assembly of images, of quotes. The baroque mind began to collect that unique moment in which language could not overarch its moment of in absentia.

The whole human body cannot enter a symbolical icon, but it is not inappropriate for part of the body to constitute it. ${ }^{6}$

Anonymus

The Baroque was a science of the gaze. What kind of trace could be traced was the question - an epistemological question. What could mankind imagine? Vesalius himself had an ambiguous position with respect to the image. Like Galen, Pliny, and his contemporaries, he had a reticence to illustrate the body due to how the pictorial abstraction produced the illusion of experience to the point of replacing it. The Renaissance artists had already managed to produce perspectivethe illusion of a spatial depth within two dimensions. Anatomical discovery had contributed to the science of proportion, in that the knowledge of the interior proved essential to its exterior representation.

Because of how it enabled a different understanding of space and movement, the anatomical practice allowed the introduction of the time vector in visual representation. Anatomia became a deity of place; it projected the visual and plastic artist into new dynamic topologies and developed a more dramatic topography: the movement of life towards death. Many artists drawing the anatomical blazons insisted on the minute detail, a missing tooth in a skull, a scar, the particular sign. In order to make the image humanly credible, they undersigned it with the trace, the signature left by time instead of the signature of God. The realism that the image projected-its capacity to stage the illusion of a universal-was due precisely to how close it came to its simulation of particulars. The trace made it clear that the anatomy theatre produced a unique performance; it indexed the image to an event, to the passage of time. Despite its visions of the ephemeral, the amphitheatre managed to link the particular to the universal by means of the common trait in all the corpses: the cut. The knife, in that sense, was the very first assembly line. De fabrica proved to be an authentic semiotic factory.

\footnotetext{
6 "Integrum humanum corpus symbolicam iconem nigredi non posse, partem tamen corporis ei constituendae non essem ineptam".
} 
Vesalius feared the image would substitute the performative value of direct observation. Some things simply had to be seen and done. He wanted to inseminate with his flowering corpses the tables of other amphitheatres across Europe. He worked to enthrone anatomy, to give it the status of an art, a science. But authority, he knew, was not always achieved by opening the sore to the finger of doubting St. Thomas. Vesalius resolved that the plates be included for their effectiveness; but he always submitted them with the warning never to take them for what they were. Properly understood the tables were solely for mnemonic purposes, traces. The Fabricas' anatomical plates were tangible enough to be persuasive, albeit with the warning: noli me tangere.

In addition to the plates, Vesalius developed a system of double entries or double tallies that transformed the image into a reverse or negative emblem that acquired a very powerful allegorical immediacy. Like the emblem, the anatomical tabulae consisted of three parts: inscriptio, pictura, and subscriptio, but instead of concentrating the meaning within the emblematic figure, the tables tore the figure apart in the direction of an irrecoverable moment of performance: the dissection. If the traditional emblem pulled its subject centripetally, the scientific emblem centrifuged him. Both dialectical forces were present in the figure of the anatomical corpse.

The inscriptio indexed the plate to the particular context of the table, the table as table of contents and as the dissection table. It alluded to a series of dissections on a particular structure or motif, e.g., "First Table of the Second Book, On the muscles of the Body". A succinct description of the de/monstrated parts and their function, as well as their relation to larger discernible structures, was rendered by means of acute spatial description. During the actual dissection, however, the problem was precisely to discern the interior of the body in terms of structures, systems, organs. Some things were indiscernible because of their invisibility, some others because of their monumental cohesion. The anatomical plate created the illusion of discernment by visually articulating the table of contents to the dissecting table. The names of parts were incorporated allegorically to the body by juxtaposing the display of names to the dissecting table. [Figure 2] 
The pictura was by far the most complex element. It showed the dissected body, usually affecting a position or gesture discrepant with the dead body and yet complicit with the docility of the corpse. The latter had the double effect of concentrating the attention of the viewer on the anatomy lesson but due precisely to the paradoxical way in which it would make the corpse conceptually dis/appear. The grounds for emblematic signification-suggested by the archetypal paraphernalia and landscape elements on displaywould, however, collapse vis-à-vis the prominence of the dissected body. The result was a very original and sui-generis form of art that challenged the pictorial representation of the body at the same time it reproduced the pictorial conventions. The emblems grafted an allegorical impression, yet would not remain in their "allegoricity", creating an effect of both radiation and contraction of meaning that did not dwell in any particular aspect of the picture, not even in the depiction as a whole, but rather in a sort of "stereoscopic" perspective entirely left up to the viewer. The human figure was

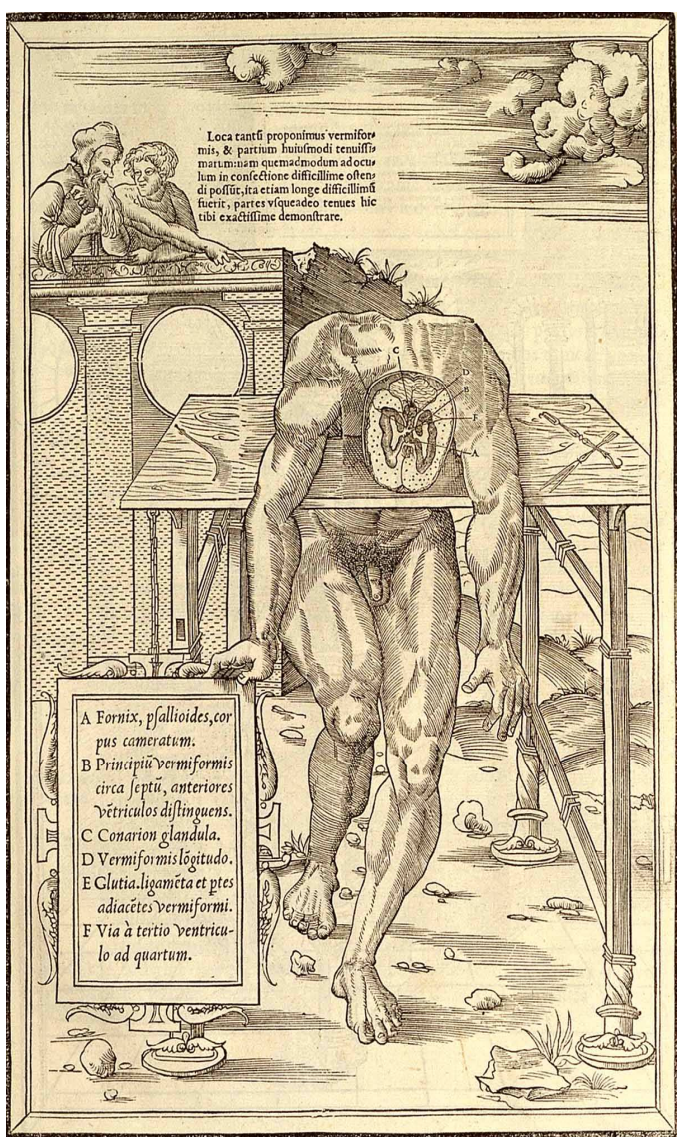

FIG. 2: La dissection des parties du corps humain...

Paris, 1546.Woodcut.National Library of Medicine. Charles Estienne(1504-ca. 1564)[author]

Étienne de la Rivière(d. 1569) [anatomist]

Draped over a table, an anatomical figure displays a cross-section of his brain while touching a frame that holds captions. In the background, spectators observe from atop a fanciful parapet. To cut costs, Estienne took some of his illustrations from nonanatomical books, replacing a section of the woodblock with an insert that depicted the body's interior. In this figure, the boundary of the insert is seen in a square around the head. depicted among ruins or barren landscapes, a motif that would allude to the passage of time, the fragmentation and decomposition of human endeavour. The anatomized surface of the subject, in accordance with the orography of the ruined landscape, would contrast with the animated positions of the depicted body. A body of lively movements and gestures was laid bare by its texture of decay. The obliviousness with which the corpse appeared occupying the 
space as if still alive produced a liminal sign. The infinite partition to which the anatomical subject was indexed contrasted with the wholesomeness of its appearance.

In the anatomical plate, a moment of impossibility stepped forth, a moment where an image could be grasped despite the void that hypostasised its apparition, a phantasmagoria projected on a screen or an act of creation ex-nihilo. The impossibility of such an act of reduction was translated onto the creation of a sign: the living corpse. The allegorical quality of the depiction mimetically vacillated between the figuratively alive and the texturally dead. "[...] The overbearing ostentation, with which the banal object seem[ed] to arise from the depths of allegory [was] soon replaced by its disconsolate everyday countenance" (Benjamin, 1977: 185). The symbol died in its figuration but was resurrected from the in/significance of a texture: the sign that was there to be seen was in the texture, in the dismemberment and partition performed during the anatomy lesson. Under the scrutiny of a scientific reading, the corpse was a blind spot because of the emblematic depiction of its anima; however, as an absent figure, the corpse rendered a very effective anatomy lesson that, by concentrating the reader on the parts, altogether killed the blind spot of allegory.

Finally, the subscriptio of the plate consisted of a series of supra-indexes that alphabetically or by similar means ordered and classified the different parts of the image while indexing the selfsame parts to their order of appearance in the table of contents. It was this method of cross-referencing that functionally articulated meaning by means of an arbitrary figure of order (the number, the alphabet) what made the plate effective, but also that generated a schizoid or disjoint sign. Time figured actively as the underwriting trace of an absent performance.

The emblematic corpse allowed anatomical findings to occupy a semantic place in the corpus of knowledge. Their dynamic spatiality dramatized a struggle for signification: the image restricted the connotative function of the arbitrary sign, at the same time it allowed a denotative definition. It pulled outwards and inwards, in the direction of a collapse or dispersion. In order to attribute meaning to the sign, it was necessary to doubly index the name, on the one hand, to an image and, on the other, to a collection of elements. In this process, the sign too became double in the sense that it was difficult to say where it lay. "[...] The will to 
allegory [made] use of the 'dumb show' to bring back the fading word, in order to make it accessible to the unimaginative visual faculty" (Benjamin, 1977: 192). Without the image, the arbitrary sign was vague or meaningless, but without the conventional sign the image had infinite readings. ${ }^{7}$ The system of double tallies introduced a space of double figurative absence, a negative dialectic that played with the potential insignificance of the absent sign. Just as the anatomist left his signature on the body and entirely receded from his work, banishing himself into the shadows, the reader had to read the absence and had to read in absence.

Cleansed of all blood, the marble will ultimately gleam; the bronzes, which are now regarded as idols, will stand innocent.

Prudentius

The anatomical plates posited a serious problem of authority: How to make others believe? In this respect, the solution that Vesalius and others found was to stage the problem. As Andrea Carlino has pointed out "Even if dissection was to be considered a transgressive and profaning act, it was tolerated because it took place at a time when every form of subversion and inversion was concealed under the guise of performance" (1999: 81). By then, anatomy theatres had naturally absorbed the conventions of the most prominent public spaces of the time. The court, the trial, the scaffold, the temple, the dramatic stage were all allegorically alluded to in the amphitheatres. An important part of the anatomy treatise was the list of dramatis personae mentioning all the prominent individuals that had attended and witnessed the spectacle. "The anatomy theatres were fashionable places in which to see and be seen" (Sawday, 1995: 190). From a textual perspective, the spectators' function was double: in witnessing the dissection, they made themselves part of the performance in the script.

The script was the means by which history became part of the setting. It stood "[...] written on the countenance of nature in the characters of transience" (Benjamin, 1977: 177). The reconstruction of the scene that the anatomist did in writing incorporated the reader as an actor; the use of the second person with which the writer addressed his reader reproduced the event

\footnotetext{
${ }^{7}$ In Benjaminian terms "This is what determines the character of allegory as a form of writing. It is a schema; and as a schema it is an object of knowledge, but it is not securely possessed until it becomes a fixed schema: at one and the
} 
in the historical present. The subjects that were dissected also figured in that list honoris causai.e., for the sake of the honour-if they had a renowned name to offer. ${ }^{8}$ As in any performance, there were actors, spectators, props and, of course, a drama. The drama began by constructing a space, by pre-empting an empty space.

The anatomical table [was] put in front of the theatre where the ancients placed the scene [...] the table was a "versatile table" hinged in the middle so that some part of the body on it (and tied to it where necessary) could be raised or lowered for easier demonstration. Above the table, in the form of a cross, were two beams providing a mechanism for raising the cadaver into different positions (French, 1999: 80) (emphasis added).

The corpse ex-machina occupied the centre of the stage. From beginning to end, the cadaver performed as a stage property. Once it entered the scene, the carcass belonged to the anatomy theatre and, as such, was manipulated on the stage for the purposes convened. But as the scalpel made the first incision, the corpse acquired a different character: it was no longer the rictus that was seen, but a carapace, a mask out of which the names for the-until theninvisible world of the organs were produced. The carcass would gradually grow into the stage, a stage inside a stage; a marionette-theatre of ligaments and nerves, muscles in shreds, liver and heart much like hand puppets.

The plates produced bodies peeling off their own skin, clothing themselves with their tissue, removing their veils, opening the Book of Adam, lifting their outer cortex in an attitude of self-display that brought the attention of the viewer to the viscera. They were shown as melancholy dolls discarded for their excised members. The corpse seemed complicit, "conspiring with its own demonstration, in order to confess the truth study which he [had] been embarked upon" (Sawday, 1995: 113). The self-demonstrating corpse had the main effect of eliminating the anatomist as an agent, especially from the gaze of those who considered his findings the execrable product of illegal practice. [Figure 3]

\footnotetext{
same time a fixed image and a fixing sign" (1977: 184).

${ }^{8}$ Prominent colleagues were most welcome. Colombo, for example, mentions the dissection he practised on the distinguished physician, Antonio Musa Brasavola (1500-1555) (French, 1999: 201).
} 
The body, depicted in willing participation, defined the anatomical subject: a figure where morphology and function exceptionally coincided (Sawday, 1995: 112); by showing its mechanic structure the body also performed the movement enabled by that structure, an im/posture. The anima appeared inseparable from its torsions, as well as disjoint from the open ribcage of its torso. In death, the body came to life. Despite the spectacle of its own division, the figure of the anatomical plate seemed to animate the body in all its purity: it defined a subject of material pure will. The carcass mimed the face of the dissector: the body was contrived to the willing rendition of its disjecta membra. The body's soul was encoded in that sole act of last will.

The spatula, scalpel, sondae, claws, razors, pliers, chisel, saw, string, wire-cutters articulated from inside the cadaver a show that brought the organs out from their shadows. The body was

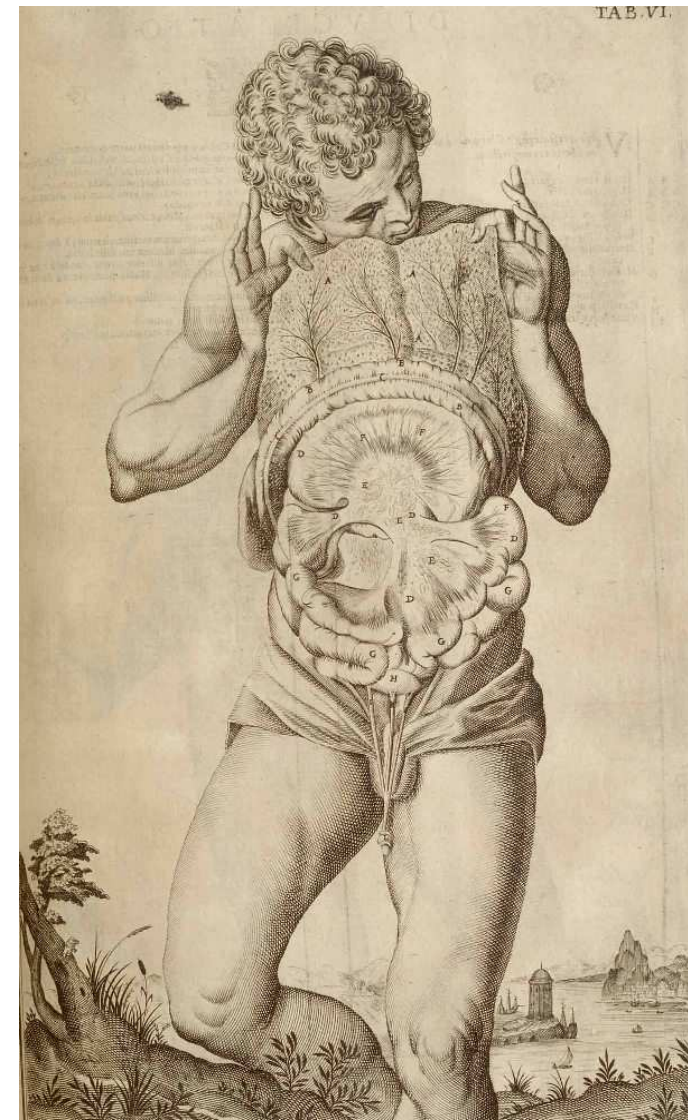

FIG. 3: Tabulae Anatomicae...

Venice, 1627. Copperplate engraving. National Library of Medicine.

Giulio Casserio(ca. 1552-1616)[anatomist] OdoardoFialetti[artist]

Some of Casserio's plates stage a not-so-subtle flirtation. Here the model coyly hides behind a veil of his own body tissue as he bares his innards. rendered as a complex machinery, an automaton, an entelequia moved by reti mirabiliwonderful nets. The dead body performed as a meta-spectator, a creature that in displaying its interior and observing itself being displayed occupied both the centre and the periphery of the event that took place. A corpse dissected by the self-same corpse. The importance of having the anatomy lesson executed by one single character gave the anatomy theatre a staging force that it did not have before. The one-manned show, pulling all the strings together towards an axle, articulated the inside/out into a seamless narrative. ${ }^{9}$ Ultimately, the carapace was a stage

\footnotetext{
9 "The duality of meaning and reality was reflected in the construction of the stage. The use of the drop-scene permitted the alternation between actions on the forestage and scenes which extended to the full depth of the stage
} 
exhibiting the wings and the proscenium arch: an empty space alien to its organicity. The backstage was inverted with the front-stage: the interior of the body became the dramatic scene with curtains, ropes and scaffolding. The stage was the place where the invisible appeared. The speculator - the physician - produced the vision of the soul out of his catoptrical box.

The soul was carved out of the body: it rendered the image of a body mapped onto itself-included and yet excluded from its contours. The body was en/graved to signify all that could be fit into the space of the amphitheatre. The corpse worked as an icon: it featured in the play as himself; it became an example of what a corpse could be. Used as an example, the dead body became an item that was set apart from its class insofar as it belonged to it; it became the antipode to the exception in the catalogue, not an included exclusion but an exclusive inclusion. ${ }^{10}$ The isolated body ceased to belong to others of its own kind-it became an excrescence. ${ }^{11}$ An example of the body was not a body. An example of death was not death. The corpse showed its own signifying, and thus, suspended its own meaning. It became a terra nulla, a page where other signs could be indexed and inscribed. But in cancelling both its dead condition and its condition as a body, for a brief instant the corpse appeared as a pure sign, as the inexistence of that which it presented.

To write history means to cite history. It belongs to the concept of citation... that the historical object in each case is torn from its context. Benjamin, Arcades Project

Anatomy originated more as a form of law practice than a medical science. Normalcy was a literal concern for legality, and on the verge of the XVI century many saw to it that it also became a matter of state. According to our modern understanding of medicine, ancient

[...] the complexities of plot could only be woven in the restricted area of the forestage; the solution took place in allegorical fullness" (Benjamin, 1977: 194).

10 "While the example is excluded from the set insofar as it belongs to it, the exception is included in the normal case precisely because it does not belong to it. And just as belonging to a class can be shown only by an example-that is, outside of the class itself-so non-belonging can be shown only at the center of the class, by an exception. In every case (as is shown by the dispute between anomalists and analogists among the ancient grammarians), exception and example are correlative concepts that are ultimately indistinguishable [...]" (Agamben, 1998: 22).

11 "The example is truly a paradigm in the etymological sense: it is what is "shown beside," and a class can contain everything except its own paradigm" (Agamben, 1998: 22). 
anatomical practice would appear rather "anomalous" given that medicine was not really dependent on anatomy. Although dissection and vivisection were practised on animals, the findings of Hippocrates, Aristotle, and later Pliny, Galen and Avicenna were not based on human anatomy. ${ }^{12}$ Opening and mutilating the dead body was considered an act of de/sacration: a form of blurring the clear cut line between the living and the dead, a way of reversing the cut and provoking the rage of the ghost from beyond the grave. But history shows that the prohibition to mutilate the corpse was nevertheless tallied to a liberal use of the knife. As an act of justice, lopping the hands and noses of thieves and other criminals was an acquiescence of those who had been injured, exerted upon the living criminal. Within ancient religious belief, the stigma became forceful precisely because it was thought to be carried over into the afterlife as an enduring disfigurement.

The Middle Ages, however, introduced a different approach to the law of dismemberment practices. The doctrine of the resurrected Christ, who innovatively effaced the qualitative differences among living beings, qualitatively conflated the living and the dead. The twofold axiom, on the one hand, of the resurrection, and on the other, of consecrated transubstantiation, meant a significant change in juridical practice. He who had risen from the dead-who had even come to raise the dead-ensured the body an afterlife in its integrity: in the last stage of the world, the saved as well as the damned would be re-collected within their physical bodies for judgement. "The process of resurrection removed mutilations" (French, 1999: 9). Furthermore, as the bread and wine of the Eucharist actually became the flesh and blood of Christ at the moment of its enactment, the immaterial person of God became ritually understood as the visible rendition of the dismembered body. The dismembered figure was a sign of piety in all of its instances; the way the Divine Verb was remembered. Dying became the Verb. The soma-sema, the embodiment of the sign, overarched the limits of the verb to be.

\footnotetext{
12 What we here mean by the fact that medicine was not based on the dissection of the human body is that the dissection of the human body had not been assimilated and accepted by the rhetoric of representation of the anatomical practice. In other words, dissections and vivisections of the human body had taken place but in other spheres: torture, war, embalming, surgery, judicial punishment and forensic interrogation. The knowledge of the body obtained by these means was not represented as anatomy. In this sense, the medicine of the Chinese and Indian civilizations were also not based on anatomy. The Arabs did not draw pictures of the body, thus their knowledge was not represented. See Roger French, Andrea Carlino.
} 
Needless to say, the Verb was overacted. The figure of the criminal, next to the figure of Christ, emulated the trial, judgement and execution of the sacred body. The martyr or the saint, on the other hand, manifested the moment of grace by which the divine "substantiated"-gave substance to-the death of those who devotedly partook of his sacramental body. The Athanasian symbol translated the categories of the dead to those of the living. The immanent expression of the divine seemed to have the paradoxical trait of material profuseness. The saints were sowed and irrigated in every European city. The toe, the tears, the tongue, the milk, the teeth, the tiniest splinter of the femur were kept and treasured both as a source of divine grace and as the legitimate sign of place (i.e., as the sign that actually took place, that by being re/located rendered the origin of a place). Martyrdom produced a collection parallel to the catalogues of the juridical body, one where the varied fragments of the body became a miraculous repository of the whole.

The rhetoric of material after-life was carried onto all of those who claimed to be the vicars of divine power. As a figure in which the image of Christ and the word of God emblematically converged, the body of the king was the rule and the exception: according to Kantorowicz's distinction, the body politic was preserved, but the body natural could be dispersed. In Northern Europe, many kings expressed the wish to have different parts of their bodies buried at different places when dying away from their homeland (French, 1999: 11).13 The metonymy of power scattered their corporeal remains but zealously collected the sovereign regalia.

The way the amphitheatre created a space of legitimacy for itself held a symbiotic relation with the spheres of power. Anatomists like Alessandro Benedetti, Charles Estienne, Johannes Dryander, Berengario da Carpi, Realdo Colombo, Juan Valverde and the well known Andreas Vesalius, among many in the XV and XVI century, continuously addressed their

\footnotetext{
${ }^{13}$ The attitude of the Church towards anatomy was undecided and completely ambiguous. "[...] in practice there were some restraints on what could be done with a dead body. Crusaders had been in the habit of disembowelling important colleagues who had died far from home and boiling their bodies so that they could send home the bones for burial unencumbered with flesh. Pope Boniface VIII in 1300 thought that this was a disgusting and horrible practice and decreed against it on pain of excommunication [...] The anatomy of Guido Vigevano (d. 1345) opens with words that make it plain that the Church did not always approve of dissection. He nevertheless boasts about how much of it he has done" (French, 1999: 11).
} 
treatises to the powerful princes and kings of Europe, as was the literary convention, in hope not only of legitimating their practice but of ensuring a constant legal supply of bodies. England, during the reign of Henry VIII, passed an Act providing for the supply of corpses to the Barber-Surgeons (1540); it is estimated that four to six bodies from the gallows were given for dissections out of a total of some 560 executions per year (Sawday, 1995: 56). In some cases, the welcoming response of the authorities even determined the manner in which outlaws began to be executed. The Grand Duke of Florence, for instance, condemned criminals to be drowned, so as to avoid damaging the neck of the corpses, although that had the disadvantage of ruining the lungs and other organs (French, 1999: 100). The anatomical dissections went hand in hand with executions. Like the latter, public anatomies were often held at the time of the carnival. The amphitheatres, in this sense, reinforced the lawabiding message that underlay in the spectacle offered at the gallows.

Lacking a central ordering instance, the notion of health and well-being drew meaning from all other public spheres of society while symptomatically re-signifying them in its terms. It was Anatomia, "the goddess of reductive division" (Sawday, 1995: 188), who, paradoxically, saw to it that medicine not only integrated its corpus as a science, but that it be co-defined by the integral corpus of the state. Medical scientific endeavours were placed next to those of the state apparatus. The convenience of medicine in the guise of the anatomical lesson working in unison with the state was geared towards the subjection of the individual's life. [Figure 4]

The knife assembled on its edge a narrative

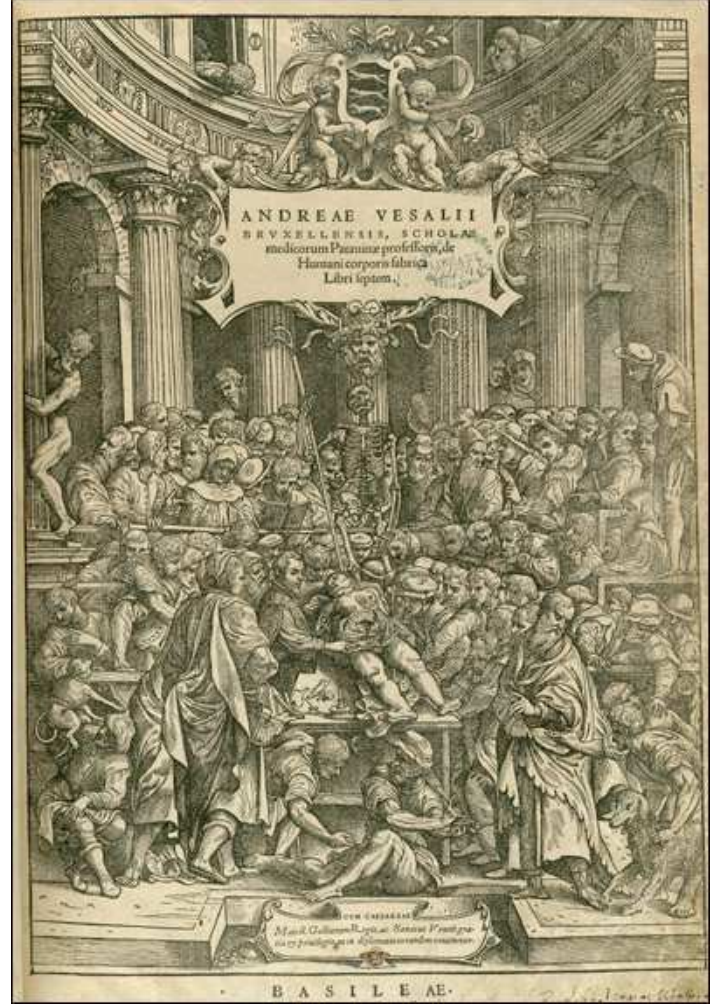

FIG. 4: De Humani Corporis Fabrica... Basel, 1543. Woodcut. National Library of Medicine. Andreas Vesalius(1514-1564)[anatomist]

Stephen van Calcar and the Workshop of Titian[artists]

Vesalius dissects a cadaver in the center of a crowded anatomical theater, while Death hovers over the scene. Before De Fabrica, depictions of dissection had the anatomist presiding at some distance from the cadaver, while lower ranking barber-surgeons did the dirty work of dissecting. 
of both ontological and deontological nature. By an act of negative ontology, the sharp edge amputated the excrescence from the excessive being (the all too living); it enacted "the living prefix with privative force": non-being was the primary trait of de-ontology. Rather than emanating from an ontological narrative, the law was built upward from the ruins: the corpses were integrated into the body of law as a no-body. The anatomist was solely an agent of character; the true character was not the anatomist, but the knife that in gouging out an eye rendered the law of the primeval God anew: "Eye" for an eye. As such, the lex talionis had been the first map of the body; it remained the first recorded catalogue to index a body part to the figure of a crime. It was also the first mirror.

The blade had the power to attribute the "Eye" to the "Me." This, however, reverberated in other humanist formulae: Nosce te Ipsum (Know Thyself), Pulvis et umbra sum (We are dust and shadows), Nascentes Morimur (We are born to die). For this very reason, dissection did not necessarily have the stigma of criminality, especially among the humanists. At the opening of the XVI century, it even became prestigious for the educated to concede their bodies to this final performance. The powerful and the saintly allowed their bodies to be dissected, perhaps because the obverse of the memento mori was salvation. The body attained an immaterial afterlife by its material surrendering. In it there was a certain aura, a silent blaze of Glory, that the body conceded to the name. Il corpo giustiziato made the body be one to itself and to a collectivity, a source of knowledge; the material existence of man thus justified, judged and mortified. This is how we learn from Realdo Colombo that Ignatius Loyola, founder of the Jesuits, had stones in the kidneys, lungs, liver and vena cava; that Francesco Capelli, the distinguished teacher called by Pope Paul IV himself to teach at the Hospital of the Holy Spirit, had "bones in the lungs and preternatural tumours and ulcers in the heart", and that Cardinal Ardinghelli had "26 teeth and strange muscles in his forehead" (French, 1999: 201). In a very humanistic manner, the anatomy theatre transposed to its incisions, to its cabinet of tools, the levelling power of death, a capacity to efface the difference, and process all bodies under the same sign: that of the incision. Even among the powerful the body betrayed their anomalies, they harboured florid diseases, and hid the signs of their monstrum naturae. 
The anatomist wove a narrative between the mirror and the knife. Both objects were already emblematic attributes of the goddess Anatomia, but their meaning was imported from other ágoras. The power that nature had over life manifested itself as death. At this moment in history, ideas on death had already begun to change. Life had ceased to be seen as the common trait of a collectivity because death had come to be seen as a moment of individual precedence. The life of each individual became distinct due to how death completed-and many would say, perfected-his existence. Death had an individual character; a person did not just die any death, he died his own death. What had till then been ritually subsumed by the religious apparatus became a matter of political concern. Death was not only the moment that defined the life of each individual, but the trait that defined each individual as individual. The corpse, in this respect, was the last trace left behind; the material body was the last individual trait. Politically speaking, the deceased body stood not for the dissolution of the subject's identity, but quite the contrary.

Characterized in its entirety by death, the corpse would embody that last moment by which the individual became a complete subject. As the subject remained beyond the instances of death, the corpse undersigned its perfect subjection. The no-man's land of the dead body was used to signify the prevalence of a person's political life. The constituting legitimate element that defined the juridical person in the corpus of the law was that he remained a subject, as a subject of death. Thus, the dead subject personified the prototype subject of the state. ${ }^{14}$ The state determined all the ways and instances by which its subjects could die. The state achieved complete jurisdiction over the death of its subjects by subsuming into its corpus of law the empty space left by death: the corpse became the sign of political life.

\footnotetext{
14 " $[\ldots]$ the production of bare life is the originary activity of sovereignty. The sacredness of life $[\ldots]$ originally expresses precisely both life's subjection to a power over death and life's irreparable exposure in the relation of abandonment [...] Bare life is banned from the State in the figure of death. The state ultimately regulates the death of its subjects, it subjects the death of its members [...]" (Agamben, 1998: 83).
} 
Laisse un Roi tout seul, sans aucune satisfaction des sens, sans aucun soin dans l'esprit, sans compagnie, penser à soi tout à loisir, et on l'on verra qu'un Roi qui se voit est un homme plein de misères, et qu'ils les ressent come un autre.

Cysarz

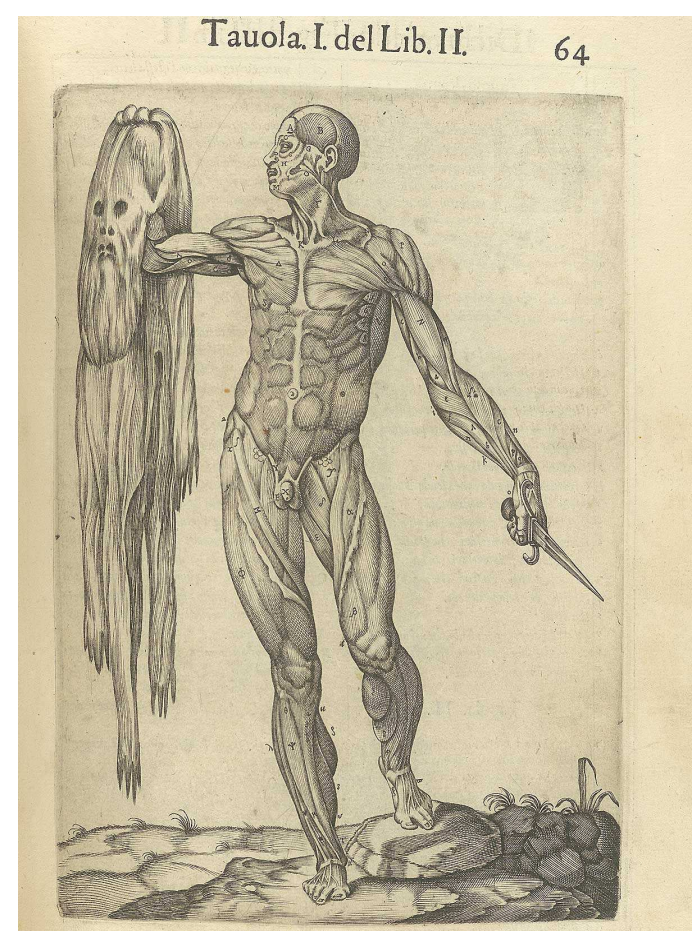

FIG. 5: Anatomia del corpo humano...

Rome, 1559. Copperplate engraving. National Library of Medicine.

Juan Valverde de Amusco(1525-ca. 1588) [anatomist]

Gaspar Becerra? [artist]

Valverde playfully shows the body dissecting its verv own skin.
A column of flesh steps down from its touchstone, knife in hand. The etching of Juan Valverde's Historia del Cuerpo Humano (1556) merges the mythological characters of Marsyas and Apollo into a figure which would be the recurrent anatomy motif of the baroque: the flayed image of mankind. The écorché brandishing its skin is the allegory of a god, a man and the king between. [Figure 5]

Apollo was the emblem of the sovereign, he was the ruling sun god, the avenging pontiff, the greatest of all celestial bodies. Legend has it that jealous of Marsyas' talent with the flute, the lyrical god challenged the satyr to a contest whose winner would do as he pleased with the defeated. Marsyas consented, and the Muses judged the agon. The satyr won the first round. But in the second, the god made use of his good rhetoric: he turned his lyre upside

down and not only did he play it but-as he persuasively argued-also sang, turning his voice into another instrument. Marsyas, a simple mortal, had after all only been capable of playing one end of the flute, one thing at a time, and not even back and forth. His art proved to be mortally irreversible. The rest became history; the mourning tears that sylvans, nymphs and shepherds shed for Marsyas came to form the river that bears his name at Celaenae. Marsyas was tied up to a pine tree and flayed alive.

Why do thou tear me from myself, he cries? Ah cruel! Must my skin be made the prize? This for a silly pipe? He roaring said, 
Meanwhile the skin from off his limbs was flay'd.

All bare, and raw, one large continu'd wound,

With stream of blood his body bath'd the ground.

The blueish veins their trembling pulse disclos'd,

The stringy nerves lay naked, and expos'd;

His guts apper'd, distinctly each express'd,

With ev'ry shining fibre of his breast. (Ovid, VI 556-565)

Frazer suggests that the tale of Marsyas' skin probably came from an old ritual in which a priest was sacrificed, and that, eventually, the ritual incorporated an effigy as a prop for the ceremony. The doubling of an exemplary figure into his human and divine components seemed, if anything, most fit for the figure of a sovereign. As Kantorowicz demonstrated, the late medieval juridical fiction which discerned two bodies in the persona of the king proved crucial in the state formation drama of the XVIIth century. ${ }^{15}$ Benjamin, on his part, places the sovereign at the centre of the allegorical baroque intention. The sovereign, as the principal exponent of history, is the mourning play's incarnation. The tyrant and the martyr constitute the two faces of the monarch. The baroque concept of sovereignty emanates from a discussion of a state of emergency, the extemporaneity that Agamben has termed "an included exclusion."

It is due to this impersonation of the king, that Benjamin sees in the sovereign of the mourning play the melancholy of the puppet. The king becomes the "emblematic property" of the baroque theatre (Benjamin, 1977: 217). As christomimétés, the Christian ruler acquired the character of an "actor" or "impersonator" of God's power, a power that came from God's nature and was conceded to the king by grace. Even if the sovereign bore the facies hippocraticathe skull, the hypocritical face, the mask of death-his mortality allowed him to attain his perfection. The body natural of the king, which in life had been visible to all, would at the sovereign's funeral become invisible-enclosed as it was in a coffin-albeit rendering his body politic visible by means of a doll that, clad in pompous regalia to his image and likeness, would

\footnotetext{
${ }^{15}$ For the King has in him two Bodies, viz, a Body natural, and a Body politic. His Body natural [if it be considered in itself] is a Body mortal, subject to all Infirmities that come by Nature or Accident, to the Imbecility of Infancy or old Age, and to the like Defects that happen to the natural Bodies of other People. But his Body politic is a Body that cannot be seen or handled, consisting of Policy and Government, and constituted for the Direction of the People, and the Management of the public weal, and this Body is utterly void of Infancy, and old Age, and other natural Defects and Imbecilities, which the Body natural is subject to, and for this Cause, what the King does in his Body politic, cannot be invalidated or frustrated by any Disability in his natural Body. (Plowden, apud Kantorowicz, 1957: 7).
} 
be displayed next to his coffin. The cult of the king's image materialised the king's ubiquity in court by displaying the ruler's portrait in all the rooms of the palace.

At death, the king's perpetuity was transposed to a doll to make it apparent that the immortality of the king was solely on account of his body politic: the body of Ius and Lex. The sovereign was the obedient vicar of God on earth who, in imitation of Christ's subjection both to the law of nature-dying before resurrection-and to the law of Caesar's divine potestasallowing himself to be judged for his fallible human nature-, fulfilled doubly the law of God in the form of Justice and Atonement. Christ's divine obedience to the Law was used to co-found the power of the sovereign as well as to subject him to the law which he embodied. The Prince had both absolute power and was absolutely circumscribed by the law.

The sovereign's incarnation of two natures legally represented by his two bodies was the means of explaining the ruler's instrumentality; namely, that the sovereign could be "conceived of as an 'instrument' of something that was not identical with him and not an immanent component of his own self" (Kantorowicz, 1957: 504). He was the "animate instrument of a fictitious, and therefore immortal, person called Dignity" (Kantorowicz, 1957: 445). The law was No-body. The king was caught in a double exception: he was the constituting power of the law and could therefore decide to be the exception to the rule; but he was also the most subject to the law and was thus forbidden to even appoint his own death. The king was the only man that could not kill himself by decree without committing murder; yet he was the only man who could appoint others' death lawfully. In his divine infallible persona, he was judge; but in his humanity, liable to "Infancy, old Age, and other natural Defects and Imbecilities," he was judged. He was neither an agent of sacrifice nor an object of sacrifice-i.e. he could not be sacrificed nor sacrifice another - because he was already a consecrated person, a person beyond the limits of life and death, neither a human nor a god but wiped out by the attributes of both. His person conflated the dead subject with the divine murderer.

The king's execution became, thus, the most exemplary act of constituting power; the empty space that his body left was pre-emptied by the sign of the body politic. The king never died, his death was an exceptional death that received the name of "demise" -i.e., the last gesture of the king was an act of will that, at all moments, constituted the transition between the 
natural body of one king to another, and that could even will to be outplayed by his own rule. The sovereign embodied a corpse, a no-sign that by the juridical machinery of the state granted him a puppet's immortality: perfect in that it brought forth the death of intention in its sheer forsaken materiality.

The écorché fleetingly captures the included exclusion of the king's body, the state of exception. The anatomical theatre fabricated a system of signification around the image of the untouchable. The untouchable image was the conceit of an absent anatomist: a body seemingly executing both the operation and the act of display. It was also the conceit of an absent draughtsman mediating between the anatomist and his corpse. What remained was the absent corpse.

Anatomy was the art of the melancholy. On his table, the anatomist essayed the monumental ruin of the body. Valverde's plate captures a moment of impossibility: a sovereign man that has managed to flay his complete being alive like a beast; Apollo and Marsyas are one The triumphant image is but a moment of self-defeat. The body never owns its own skin. Our skin always belongs to someone else, it falls apart at every gaze. The Apollonian body of the knife steps out from within its sheath. The flayed god has become a man-knife outside of his vagina, his skin-sheath. Apollo embodies the knife as its complete absence: the flayed human figure bears merely the aura of a god that plundered the skin of a satyr; all that is left of the knife is the trace of the blade, the memory of the god that inflicted the wound. The flayed god and the satyr's coat of skin reproduce an act of fertile violence: the copula of the god with himself as instrument. Like an Uroborus, man brandishes the skin of a god who flayed a satyr into its very instrument of art. The écorché steps down, knife in hand, holding up a mask of skin. Like Perseus, who could not face the Gorgon and yet cut off its head by the instrumentation of the mirror, the head of snakes - the skin - is brandished to reflect the viewer and suck him into the image of his own absence. This is where the god imagines, and the satyr perfects the art; it is a historical moment of creation: the allegorical sign stepping forth in its gleaming husk - death, unmediated. The undoing of the word by which all words fell apart, the Apollonian knife out of its satirical sheath mimes the deadly copula of the verb to be. The secret flaying of the god taints the image with the ghastly presentiment that art involves the dialectics of a vivisection. 
To Benjamin, one thing held true to the baroque: texture brought the text to ruins. The anatomy theatre brought forth a profusion of enfolding surfaces. It rendered the interior as an extended skin. The frontispieces appearing on the covers of the volumes, the brutal façades, all conjured up the resurrected torsions of the corpse. The times had a penchant for one Final Judgement. The corpses were summoned to appear before a different judge, a court not of putti and cherubs, but of much baser thrones and much larger throngs. It was no longer Adam's tongue, rib, eve, that was called to court; it was something subtler than the skin of both his eyes, it was his gaze: mankind hoped to make him confess what he had seen. What was so ineffable in Adam's nakedness that, upon the act of seeing, God covered him in skin? The text merged with its shroud of decaying embroideries, gently receding into the sewn leaves of the strangler fig. It purchased the mournful semblance of the fallen creature that, ruined, fell silent on the surface of its skin. Had Adam been stripped from his coat of skin (Genesis, 2:21), would the pain have bought the debt? Being the skin the proof of Adam's fall, would Adam's flaying undo the sin? Perhaps the serpent always knew the secret would be shed; the skin of death remained the most prized spoil; the dream of a god or at least a king. 


\section{Bibliography}

AGAMBEN, Giorgio (1998): Homo Sacer: Sovereign Power and Bare Life (trans. Daniel Heller-Roazen), Stanford: Stanford UP.

BENJAMIN, Walter (1969): Illuminations: Essays and Reflections (trans. Harry Zohn), New York: Schocken Books.

- (1977): The Origin of German Tragic Drama (trans. John Osborne), London: NLB.

- (1978): Reflections: Essays, Aphorisms, Autobiographical Writings (trans. Edmund Jephcott), New York: Harcourt Brace Jovanovich.

- (1999): The Arcades Project (trans. Howard Eilan and Kevin McLaughlin), Cambridge: Harvard University Press.

CARLINO, Andrea (1999): Books of the Body: Anatomical Ritual and Renaissance Learning (trans. John Tedeschi and Anne C. Tedeschi), Chicago: University of Chicago Press.

CERONETTI, Guido (1993): The Silence of the Body: Materials for the Study of Medicine (trans. Michael Moore), New York: Farrar, Straus, and Giroux.

CHEVALIER, Jean and Alain Gheerbrant (1995): Diccionario de los símbolos (trans. Manuel Silvar y Arturo Rodríguez), Barcelona: Editorial Herder.

CLARKE, Bruce and Wendell Aycock (eds) (1990): The Body and the Text: Comparative Essays in Literature and Medicine, Lubbock: Texas Tech UP.

DALY, Peter M (1998): Literature in the Light of the Emblem: Structural Parallels Between the Emblem and Literature in the Sixteenth and Seventeenth Centuries, Toronto: University of Toronto Press.

DELEUZE, Gilles (1993): The Fold: Leibniz and the Baroque, (trans. Tom Conley), Minneapolis: University of Minnesota Press.

FALCÓN MARTÍNEZ, Constantino, et al. (1989): Diccionario de la mitología clásica (2 volumes), México: Alianza Editorial.

FRAZER, James George (1971): The Golden Bough: A Study in Magic and Religion, New York: Macmillan.

FREEDBERG, David (2002): The Eye of the Lynx: Galileo, His Friends, and the Beginnings of Modern Natural History, Chicago: The University of Chicago Press.

FRENCH, Roger K. (1999): Dissection and Vivisection in the European Renaissance, Aldershot: Ashgate.

GRAVES, Robert (1965): The Greek Myths, London: Cassell.

JACOBS, Noah Jonathan (1958): Naming Day in Eden: The Creation and Recreation of Language, New York: Macmillan.

KANTOROWICZ, Ernst Hartwig (1957): The King's Two Bodies: A Study in Mediaeval Political Theology, Princeton: Princeton UP.

King James Bible. http://bible.gospelcom.net/

OVID (1994): Metamorphoses (trans. S. Garth and J. Dryden), New York: Garland.

- (1989): Fasti (trans. J.G. Frazer), Cambridge: Harvard UP.

OWENS, Margaret Ellen (1994): Dismemberment and Decapitation in the English Renaissance Stage: Towards a cultural Semiotics of Violent Spectacle. Ph.D., Graduate Department of English, University of Toronto.

PINKUS, Karen (1996): Picturing Silence: Emblem, Language, Counter-Reformation Materiality, Ann Arbor: University of Michigan Press.

SAWDAY, Jonathan (1995): The Body Emblazoned: Dissection and the Human Body in Renaissance Culture, New York: Routledge.

WYSS, Edith (1996): The Myth of Apollo and Marsyas in the Art of the Italian Renaissance: An Inquiry into the Meaning of Images, Newark: University of Delaware Press. 